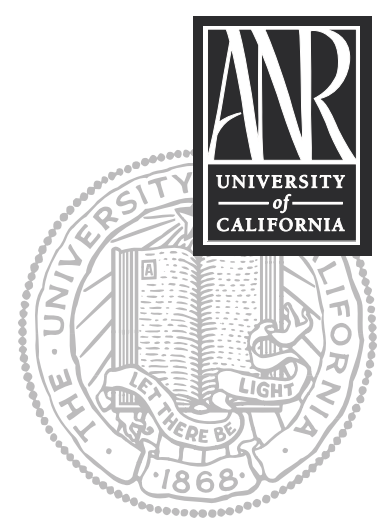

UNIVERSITY OF CALIFORNIA

Division of Agriculture and Natural Resources http://anrcatalog.ucdavis.edu

\title{
Selecting Lumber and Lumber Substitutes for Outdoor Exposures
}

STEPHEN L. QUARLES, UCCE Wood Durability Advisor, UC Richmond Field Station; JOHN W. KOBZINA, UCCE Master Gardener, Contra Costa County; and PAMELA M. GEISEL, UCCE Farm Advisor, Fresno County.

In California, naturally durable woods such as redwood and other lumber that has been chemically treated to improve durability have long been used in landscape, garden, and structural applications that require increased resistance to wood-eating insects (termites and beetles) and decay fungi. Until the wood-treating industry voluntarily halted its residential use in January, 2004, the arsenical preservative chromated copper arsenate (CCA) was the most common for residential applications. Health concerns regarding human contact with arsenic leached from the lumber resulted in this voluntary withdrawal. The U.S. Environmental Protection Agency accepted the withdrawal, but does not recommend the replacement of existing structures made with the lumber or any removal of soil surrounding CCA-treated lumber [US EPA 2002].

Alternative products have always been available for many exterior applications, but growing consumer interest in lower-maintenance products, combined with a certain degree of concern over the use of old-growth redwood, has increased the demand for other products such as plastic-lumber composites. Slower-growing (old-growth) redwood and other naturally durable species are still available, but faster-growing (young-growth) redwood is more common. The production of all-plastic lumber and fiber-plastic lumber composites has been a growth industry in recent years, and a number of brands are now available to consumers.

Wood cannot rot if its moisture content remains low enough, so keeping wood dry is one way to increase its useful service life. Keeping wood dry, however, can sometimes be difficult. Treated woods have been used where untreated wood would not last long: an increase in useful service life and safety was balanced against any potential environmental impacts that could result from the use of chemically treated wood. Typical uses include structures in direct contact with the ground or water (decks, retaining walls, raised-bed gardens, piers for boat docks) and other applications where wetted lumber could only dry very slowly.

With the growing use of new lumber treatments and lumber substitutes, a number of questions arise: How long can the newer non-arsenically treated lumber last in severe exposure situations? Are there any performance and durability issues associated with lumber substitutes used in common applications where treated lumber would otherwise be used? This publication is a guide to the options available to do-it-yourselfers and contractors who use building materials in more severe exterior exposures.

\section{MATERIALS AVAILABLE}

Depending on the application, you have a variety of alternatives to CCA and other non-arsenical preservative treated lumber (pressure-treated lumber) (Table 1). These include untreated lumber and fiber-plastic composite lumber. For certain applications, particularly raised-bed gardens, concrete blocks are an appropriate alternative material. Additionally, certain design features can reduce the potential for rot, such as the use of plastic sheeting laid between treated lumber and soil. This also minimizes the contact between any chemicals that might leach from treated lumber and the soil that contains garden plants. 
Table 1. Summary of suitability information for common alternative materials used in specific applications.

\begin{tabular}{|c|c|c|c|c|}
\hline \multirow[b]{2}{*}{ Application } & \multicolumn{4}{|c|}{ Material } \\
\hline & Untreated wood & $\begin{array}{l}\text { Treated wood } \\
\text { (non-arsenical) }\end{array}$ & $\begin{array}{l}\text { Plastic composite } \\
\text { lumber }\end{array}$ & $\begin{array}{l}\text { Stone, concrete, } \\
\text { concrete blocks (CMUs) }\end{array}$ \\
\hline Deck boards & $\begin{array}{l}\text { Acceptable; best } \\
\text { results with a durable } \\
\text { species. If stained } \\
\text { appearance is desired, } \\
\text { re-staining is required } \\
\text { every } 12-18 \text { months. }\end{array}$ & $\begin{array}{l}\text { Acceptable, but other } \\
\text { materials (untreated } \\
\text { wood or plastic com- } \\
\text { posite lumber) may be } \\
\text { more desirable. }\end{array}$ & $\begin{array}{l}\text { Acceptable; fire } \\
\text { susceptibility of some } \\
\text { products may limit } \\
\text { use in some areas. }\end{array}$ & Not applicable \\
\hline $\begin{array}{l}\text { Deck support joists } \\
\text { and beams }\end{array}$ & $\begin{array}{l}\text { Not the best choice, } \\
\text { but untreated Doug- } \\
\text { las-fir joists are cur- } \\
\text { rently used in many } \\
\text { decks. Special precau- } \\
\text { tions to protect joists } \\
\text { from moisture would } \\
\text { extend service life. }\end{array}$ & $\begin{array}{l}\text { Acceptable, and } \\
\text { required (by building } \\
\text { code) in many loca- } \\
\text { tions. }\end{array}$ & $\begin{array}{l}\text { Not acceptable due to } \\
\text { structural limitations, } \\
\text { however it is com- } \\
\text { monly used for post } \\
\text { and railing applica- } \\
\text { tions on decks. }\end{array}$ & Not applicable \\
\hline Marine environments & Not acceptable & $\begin{array}{l}\text { Acceptable with } \\
\text { appropriate chemical } \\
\text { loading. Some pre- } \\
\text { servative treatments } \\
\text { are not allowed due } \\
\text { to environmental } \\
\text { concerns. }\end{array}$ & $\begin{array}{l}\text { Acceptable for non- } \\
\text { structural applications } \\
\text { (e.g., fender piles). }\end{array}$ & $\begin{array}{l}\text { Yes, concrete piles or } \\
\text { wraps. }\end{array}$ \\
\hline Playground structures & $\begin{array}{l}\text { Acceptable; potential } \\
\text { service life limita- } \\
\text { tions if non-durable } \\
\text { species is used or if } \\
\text { sapwood is included } \\
\text { in lumber, particularly } \\
\text { for ground-contact } \\
\text { members. Ground } \\
\text { contact portion may } \\
\text { be treated to extend } \\
\text { useful service life. }\end{array}$ & $\begin{array}{l}\text { Non-arsenical pres- } \\
\text { sure-treated members } \\
\text { are available. Would } \\
\text { be used in conjunc- } \\
\text { tion with other mate- } \\
\text { rials. }\end{array}$ & $\begin{array}{l}\text { Acceptable; structural } \\
\text { components typically } \\
\text { are reinforced. Metal } \\
\text { components are also } \\
\text { commonly used in } \\
\text { these applications. }\end{array}$ & Not applicable \\
\hline Raised-bed gardens & $\begin{array}{l}\text { Acceptable, potential } \\
\text { service life limita- } \\
\text { tions if a non-durable } \\
\text { species is used or if } \\
\text { sapwood is included } \\
\text { in lumber. }\end{array}$ & $\begin{array}{l}\text { Acceptable, especially } \\
\text { from service life } \\
\text { perspective. Some } \\
\text { leaching of copper is } \\
\text { possible, which may } \\
\text { be of concern to some } \\
\text { builders or owners. }\end{array}$ & Acceptable & Acceptable \\
\hline Retaining walls & $\begin{array}{l}\text { Not the best choice } \\
\text { due to potential ser- } \\
\text { vice life limitations if } \\
\text { non-durable species is } \\
\text { used or if sapwood is } \\
\text { included in lumber. }\end{array}$ & $\begin{array}{l}\text { Acceptable, especially } \\
\text { from service life } \\
\text { perspective. }\end{array}$ & $\begin{array}{l}\text { Depending on height } \\
\text { of wall and loading } \\
\text { from behind, struc- } \\
\text { tural limitations are } \\
\text { likely. }\end{array}$ & Acceptable \\
\hline Sill plates & $\begin{array}{l}\text { Only selected spe- } \\
\text { cies and grades are } \\
\text { allowed by building } \\
\text { codes. }\end{array}$ & $\begin{array}{l}\text { Acceptable, and } \\
\text { required by building } \\
\text { code. }\end{array}$ & $\begin{array}{l}\text { Not a currently } \\
\text { accepted use. }\end{array}$ & Not applicable \\
\hline
\end{tabular}




\section{Untreated Lumber}

The durability of untreated lumber depends on the type of wood used: some species are very durable and others are not. It is important to understand that the sapwood of any species has a very low natural resistance to the organisms that can destroy lumber. For example, the white part of redwood (the sapwood) is not naturally resistant to decay, but the red part of redwood (the heartwood) is (Figure 1). The natural decay resistance of the heartwood of common commercial lumber species in the western United States and some of the more popular imported tropical hardwoods is given in Table 2.

Natural resistance to decay is caused by the extractives (nonstructural organic components found in wood) found in the heartwood. Because the amount and types of the extractives vary from species to species, so does decay resistance. These extractives also give the heartwood its color. Unfortunately, heartwood decay resistance varies within a species, and depends on the original location of the piece of lumber within the tree. This means that with the same exposure to soil or water, two pieces of lumber from the same tree could perform differently. Given our increased use of second-growth timber, many of our naturally decay-resistant species are in fact less resistant to decay than old-growth lumber. (Note, for example, that Table 2 gives old-

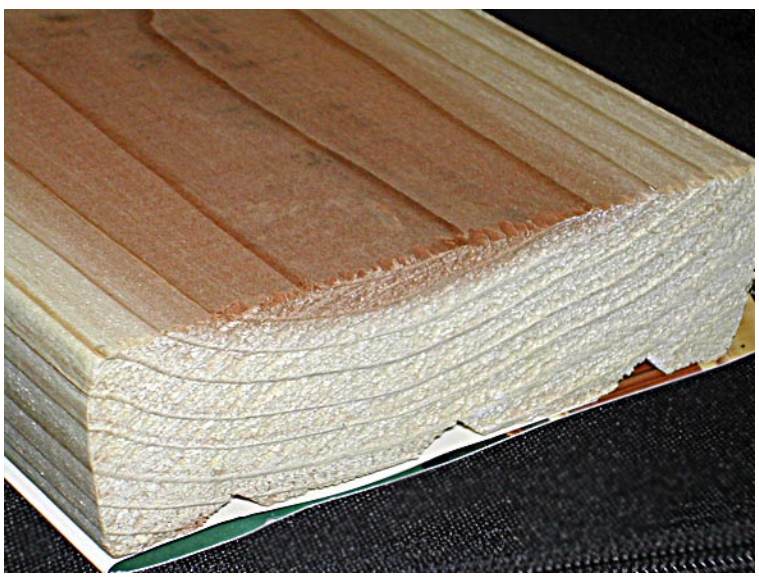

Figure 1. The sapwood of any species is not very durable. Color can often help distinguish the heartwood and sapwood of a species. In this redwood (Sequoia sempervirens) board, the reddish wood on top is the heartwood and the white portion is sapwood.

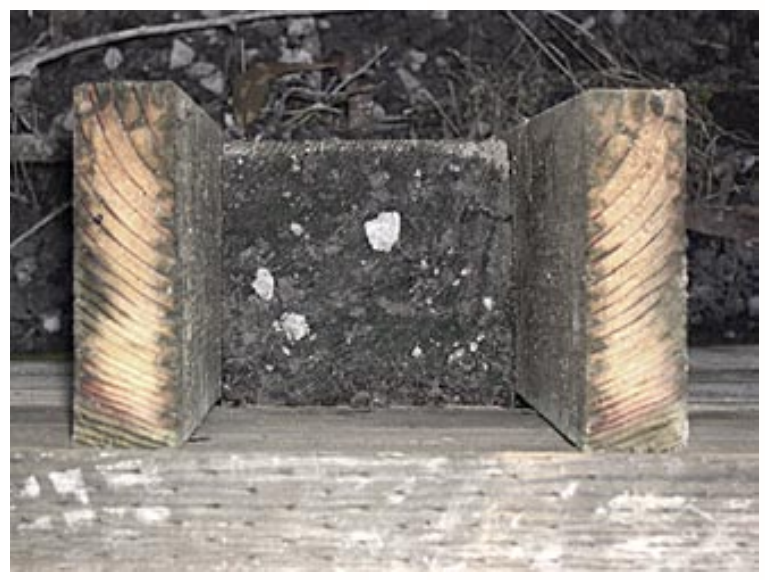

Figure 2. ACQ-treated lumber used in a retaining wall. The end-cut boards reveal a cross-section showing that only the outer shell of the lumber, where discoloration is apparent, contains the preservative chemicals. growth redwood the highest decay-resistance rating, but gives only a moderate rating for second-growth [or young-growth] redwood.)

The advantage of pressure-treated wood over naturally durable species is its greater potential for uniformity in its useful service life. From a performance perspective, the disadvantage of pressure-treated lumber, particularly species such as Douglas-fir and the Hem-fir species group (hemlock and the true firs) that are commonly used in California and the West, is that the lumber is only treated at and near its outer surface. The lumber's core usually cannot be treated (Figure 2). If the treated lumber is cut to length or if it is drilled, the user must either apply a field treatment or rely on the wood's natural

Table 2. Domestic and selected imported tropical woods, listed according to average heartwood resistance to decay (Wood Handbook, 1999). These terms (very resistant, resistant, moderately resistant, slightly resistant, and nonresistant) are intended to provide a relative measure of decay resistance and are based on standard tests where resistance to decay fungi is evaluated in a laboratory.

\begin{tabular}{|c|c|c|}
\hline $\begin{array}{l}\text { Resistant or very } \\
\text { resistant }\end{array}$ & $\begin{array}{l}\text { Moderately } \\
\text { resistant }\end{array}$ & $\begin{array}{l}\text { Slightly resistant or } \\
\text { nonresistant }\end{array}$ \\
\hline $\begin{array}{l}\text { American mahogany (true or } \\
\text { Honduras mahogany) }\end{array}$ & African mahogany & Alder, red \\
\hline Black walnut & Douglas-fir & Ashes \\
\hline $\begin{array}{l}\text { Cedars (western red cedar, } \\
\text { incense cedar, Alaskan } \\
\text { yellow cedar) }\end{array}$ & Larch, western & Aspens \\
\hline Ipe & Redwood, young growth & Firs, true \\
\hline Junipers & Southern yellow pines & Hemlocks \\
\hline Oaks, white & \multirow[t]{5}{*}{ Teak, young growth } & $\begin{array}{l}\text { Meranti or Luan } \\
\text { (Philippine mahogany) }\end{array}$ \\
\hline Pacific yew & & Oaks, red \\
\hline Redwood, old growth & & $\begin{array}{l}\text { Pines (sugar pine, ponderosa } \\
\text { pine, lodgepole pine) }\end{array}$ \\
\hline \multirow[t]{2}{*}{ Teak, old growth } & & Tanoak \\
\hline & & Yellow-poplar \\
\hline
\end{tabular}


Table 3. Estimated service life of representative treated and non-treated lumber. ${ }^{*}$ For this table, it is assumed that non-treated lumber contains no sapwood.

\begin{tabular}{|l|c|c|}
\hline & \multicolumn{2}{|c|}{ Service life } \\
\cline { 2 - 3 } & $\begin{array}{c}\text { Not in contact } \\
\text { with the ground }\end{array}$ & $\begin{array}{c}\text { In contact with } \\
\text { the ground }\end{array}$ \\
\hline Untreated: & $10-15$ years & $3-6$ years \\
\hline Douglas-fir & $5-10$ years & $1-3$ years \\
\hline Ponderosa pine & $50+$ years & $20+$ years \\
\hline Redwood (old growth) & $15-25$ years & $10-15$ years \\
\hline $\begin{array}{l}\text { Redwood (young growth) } \\
\text { Treated: }\end{array}$ & $30+$ years & $30+$ years \\
\hline $\begin{array}{l}\text { ACQ-treated Douglas-fir } \\
\text { (0.4 pounds per } \mathrm{ft}^{3} \text { retention) }\end{array}$ & $25+$ years & $25+$ years \\
\hline $\begin{array}{l}\text { CCA-treated }{ }^{\dagger} \text { Hem-fir } \\
\text { (0.4 pounds per } \mathrm{ft}^{3} \text { retention) }\end{array}$ & & \\
\hline
\end{tabular}

*Publications by Wilcox (1984) and Miller and Graham (1977) were used in developing this table. A questionnaire completed by regional wood performance experts and the senior author of this publication was also used.

${ }^{\dagger}$ CCA-treated lumber is no longer available for residential use; service life information is given here for historical reference.

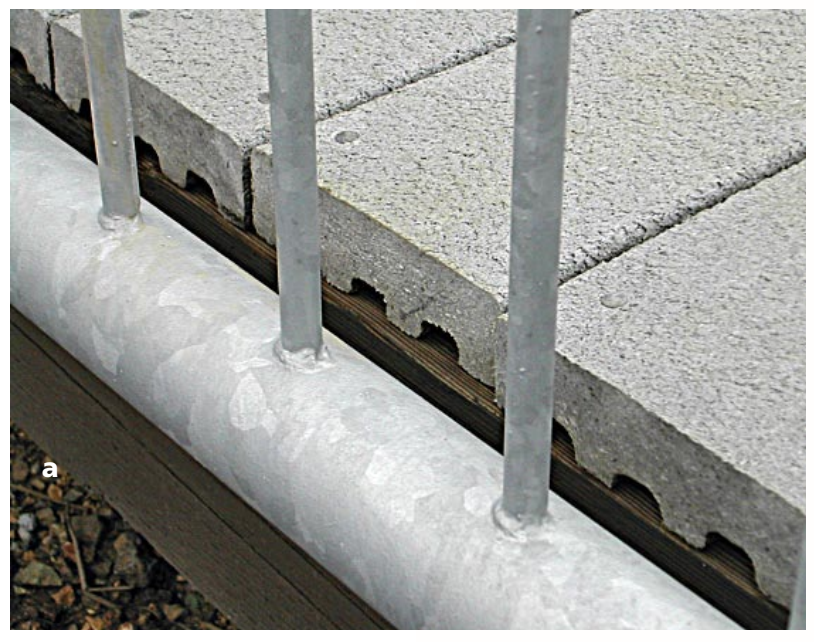

Figure 3. Plastic-lumber composite material is used for deck boards. These boards feature a channeled construction, large grooves on the underside of the boards that reduce each board's weight without reducing its strength. durability. Over-the-counter preservatives used for field treatments will be discussed later.

To help you better understand the trade-offs between treated and untreated lumber, Table 3 gives an estimate of useful service life for treated and untreated lumber based on published information and an informal survey of regional wood experts. A limited survey of local lumberyards indicated that Construction Heart grade redwood would cost about 50\% more than pressure-treated lumber. An all-heartwood grade of redwood would cost almost four times as much as pressure-treated lumber.

\section{Plastic-Lumber / Composites}

A number of plastic-lumber and fiber-plastic composite products have been introduced in recent years (Figure 3). Some of these products are $100 \%$ plastic, but many others contain wood fibers as filler and reinforcement. When present, wood fiber typically accounts for about $50 \%$ of the weight of the board. Other reinforcement fibers such as fiberglass or rice hulls are sometimes used. Many but not all of these products contain recycled plastic and wood fiber. Plastic-lumber composites have the advantage of relative resistance to biological organisms, particularly as compared to untreated wood. This is one property that gives them low maintenance requirements. Recently published research and field observations have shown that some wood-fiber-plastic lumber composite products are susceptible to at least limited fungal decay (Mankowski and Morrell 2000; Pendleton et al. 2002; Manning and Ascherl 2004). In these studies, the extent of decay was dependent on the amount of wood in the plastic composite, wood particle size, and other processing variables that affected the composite's water resistance.

According to information obtained in the limited survey of lumberyards mentioned earlier, the cost of $2 \times$ 6 plastic composite decking material was roughly twice that of $2 \times 6$ Construction Heart grade redwood, and was comparable to a " $\mathrm{B}$ " grade. A " $\mathrm{B}$ " grade of redwood is more of an appearance grade, meaning that it would contain fewer knots. The price of plastic composite lumber varied according to color, with the reddish products being more

expensive. Plastic composite lumber products typically are not as stiff as solid wood or other structural materials, so they are not used as support joists in decks. In raised-bed gardens, though, this material should perform well.

A potential disadvantage for some of these products is their vulnerability to fire (Quarles, Cool, and Beall 2004). This is an important consideration for homes located in the wildland-urban interface when these materials are used as deck boards. Finally, some plastic and plastic composite materials will expand and contract with changes in temperature, so builders might have to provide gaps between boards during construction. Information on the need for and suggested size of the between-board gap should be available from the product manufacturer. 


\section{TREATED LUMBER OPTIONS}

\section{Field Treatments ("Over-the-Counter Preservatives")}

Lumberyards and hardware stores stock a number of wood preservatives and treatedlumber products. The wood preservatives stocked by these stores are generically referred to as over-the-counter preservatives because they are readily available to individuals who have not received any special training in chemical use or handling. Overthe-counter preservatives are applied to wood products by either spraying, brushing, or dipping. They are also used on the ends of pressure-treated lumber that has been cut to length or on untreated surfaces that have been exposed by drilling. Preservatives applied in this way do not penetrate very deep, and so should only be thought of as a surface treatment. Greater penetration can be expected when the chemicals are applied to the end grain than when applied to side grain. Also, you can expect a five-minute dip to provide greater penetration that a spray-on or brush-on application (Figure 4).

A number of fungicides are used commercially in paints and stains to minimize

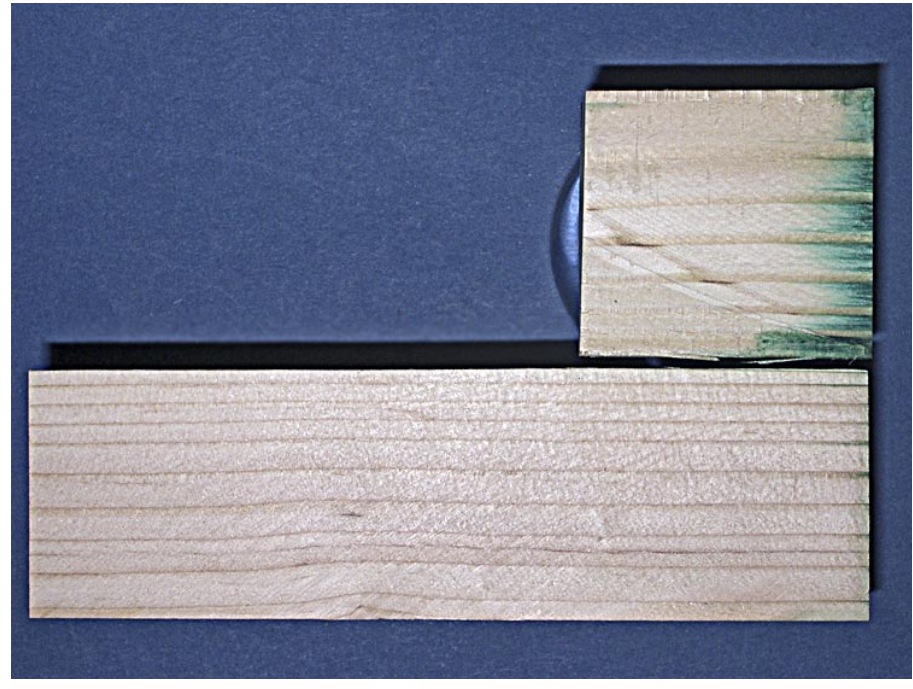

Figure 4. Penetration of copper naphthenate into the end grain of Douglas-fir. A five-minute dip treatment (upper) provided greater penetration than a brush-on application. Typical penetration for the dip treatment was a little more than $1 / 4 "$.

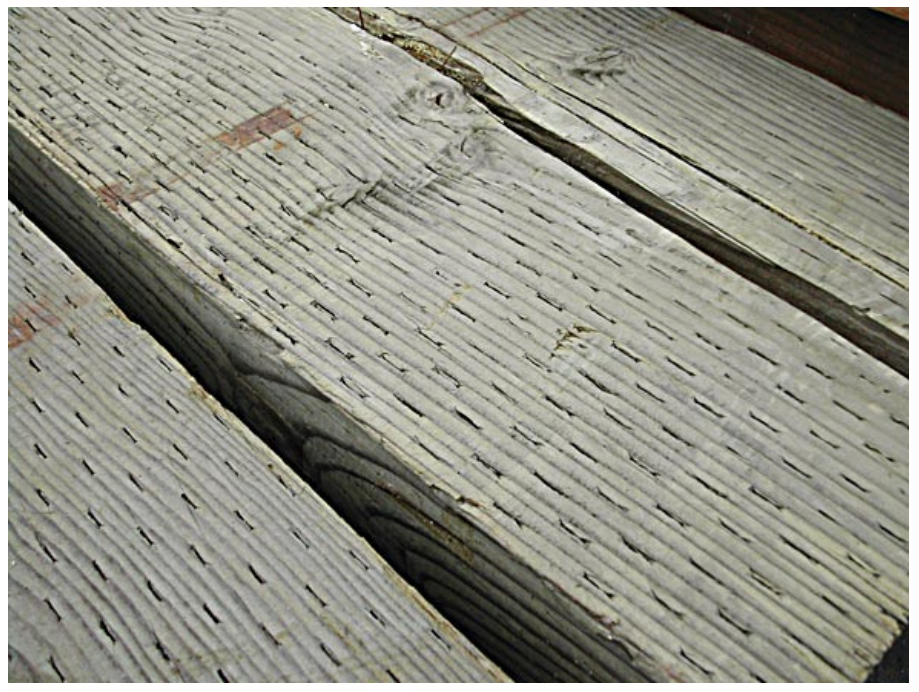

Figure 5. Incised lumber shows visible marks where knives have cut into the lumber surface. Lumber is incised before treatment with preservatives so the chemicals will be able to penetrate deeper into the wood. the growth of mold fungi (mildew), but only a few are used commonly in over-the-counter preservatives for lumber. The most common are copper naphthenate (typically a green solution) and zinc naphthenate (typically a clear solution). Borate-based preservatives, very effective insecticides and fungicides with low toxicity to humans and animals, are also available. The disadvantage of most borate preservatives is that they are easily leached from wood. In exposures where borate-treated lumber could be repeatedly wetted, this preservative would eventually leach away, leaving the wood unprotected.

\section{Preservative-Treated (Pressure-Treated) Lumber}

The preservative-treated lumber found in lumberyards has been subjected to a pressure treatment process using chemicals that cannot be purchased by the typical consumer. With pressure treatment, the chemicals penetrate deeper into the wood, and the result is improved durability with an associated longer service life. Narrow knife marks that are cut into the lumber surface at regular intervals also aid in penetration of the preservative. Lumber bearing these marks is said to be incised (Figure 5). Pressure-treated Douglas-fir and Hem-fir lumber more than one inch thick must be incised. Because of its large sapwood zone (which is more permeable than its heartwood), southern yellow pine is not incised. For the same reason, round members (poles) from western species usually are not incised: the more-permeable sapwood is on the outside of the tree underlying the bark, which is removed prior to treatment. Small-diameter round members called peeler cores (the part of a log remaining after veneer has been peeled off) often are pressure treated and are available for use in landscaping applications. Peeler cores are not incised, and because they only contain heartwood the preservative does not penetrate very deep. 
For a number of years now, CCA-treated lumber from the Hem-fir species group (hemlock and white fir) has been widely available in lumberyards. Because Douglas-fir is a common construction material in the West and is hard to treat with CCA, it has commonly been treated with other preservatives. These include ammoniacal zinc copper arsenate (ACZA) and ammoniacal copper quaternary (ACQ). ACZA, like CCA, is an arsenic-containing preservative, but it will continue to be available. Most Douglasfir lumber treated with ACZA has been used in commercial applications, so it is not available in all lumberyards.

Since the voluntary withdrawal of CCA, new non-arsenic-containing wood preservatives have become available. These include ACQ (with brand names such as Preserve and Nature Wood) and Copper Azole (CBA or CA, depending on whether boron is included in the formulation). Copper Azole is sold under the name "Natural Select." Other non-arsenical formulations will become available over time. In the newer non-arsenical preservatives, copper is the primary preservative, with additional co-biocides added to provide additional anti-fungal activity (Laks 1997). The treatment stamp or tag applied to each piece of treated lumber provides information on the type and amount of preservative chemical contained in the lumber (Figure 6).

Unpublished results of performance assessment for these new preservatives show that the degree of decay and insect resistance of lumber treated with the new nonarsenicals, with appropriate retention and penetration levels, can be similar to that of CCA-treated lumber. This general result is reflected in the expected service lives given in Table 2. In order to prevent premature corrosion of fasteners (nails, bolts, etc.) that can occur when they are used with pressure-treated lumber, the treating industry has always recommended the use of hot-dipped galvanized or stainless steel fasteners. This recommendation will still apply to the new preservatives. Tests conducted by Simpson Strong-Tie, a manufacturer of fasteners and connectors, have shown that many of the new-generation preservatives are more corrosive to steel fasteners than CCA (Simpson Strong-Tie 2004), making the use of stainless steel or hot-dipped galvanized fasteners even more important (Morrison 2004).

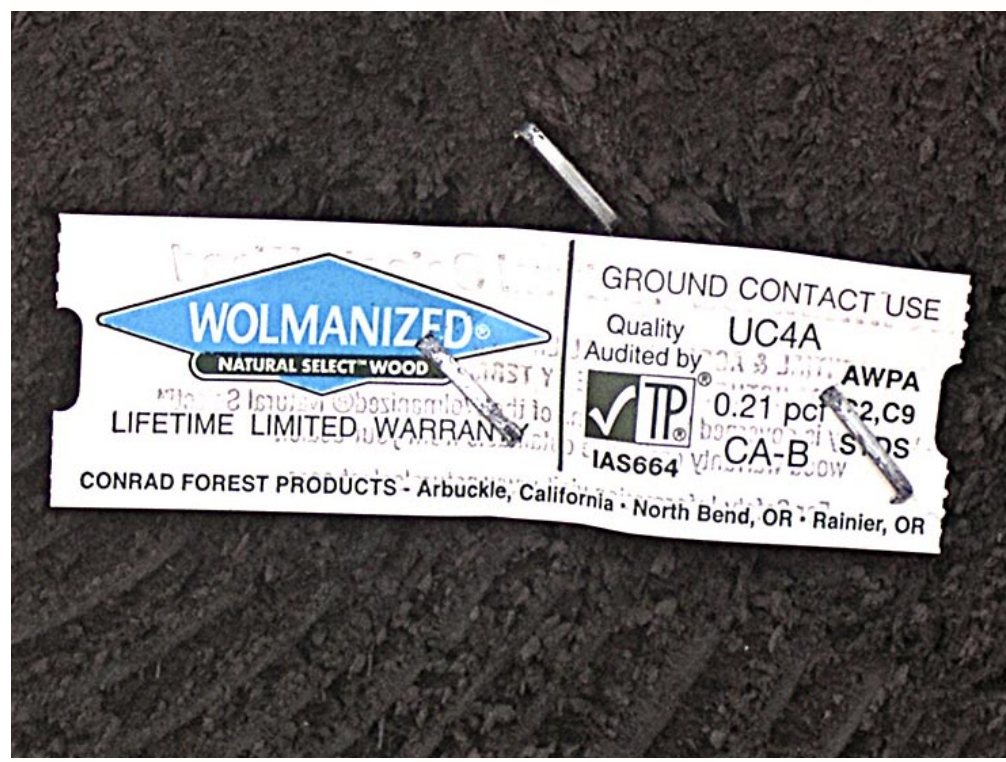

Figure 6. Typical tag on pressure treated lumber, in this case indicating the preservative chemical is Copper Azole, and that the lumber has been treated for a ground contact application. "TP" is a quality control indicator; "UC4A" refers to the lumber's application ("use category"), and is in this case is somewhat redundant with the "ground contact use" statement.
Borate-treated products, either in the form of zinc borate (typically used in oriented strand board [OSB] sheathing panels and cellulose insulation) or sodium borate (used in lumber and plywood products), are also available. Zinc borate is much less soluble than are sodium borate products, so leaching is less of an issue. Some advances have also been made in reducing the leaching tendency of other borate products, but they still are not recommended for use in freshwater- and ground-contact applications.

Preservative-treated timbers (round and square members) that contain pentachlorophenol (penta) and creosote are still produced, but are not typically available to the general public. Penta is used to treat utility poles. Creosote is commonly used to treat railroad ties and utility poles. Homeowners can sometimes find used railroad ties at a lumberyard for use in landscaping applications (Figure 7). Used utility poles are harder to find. 


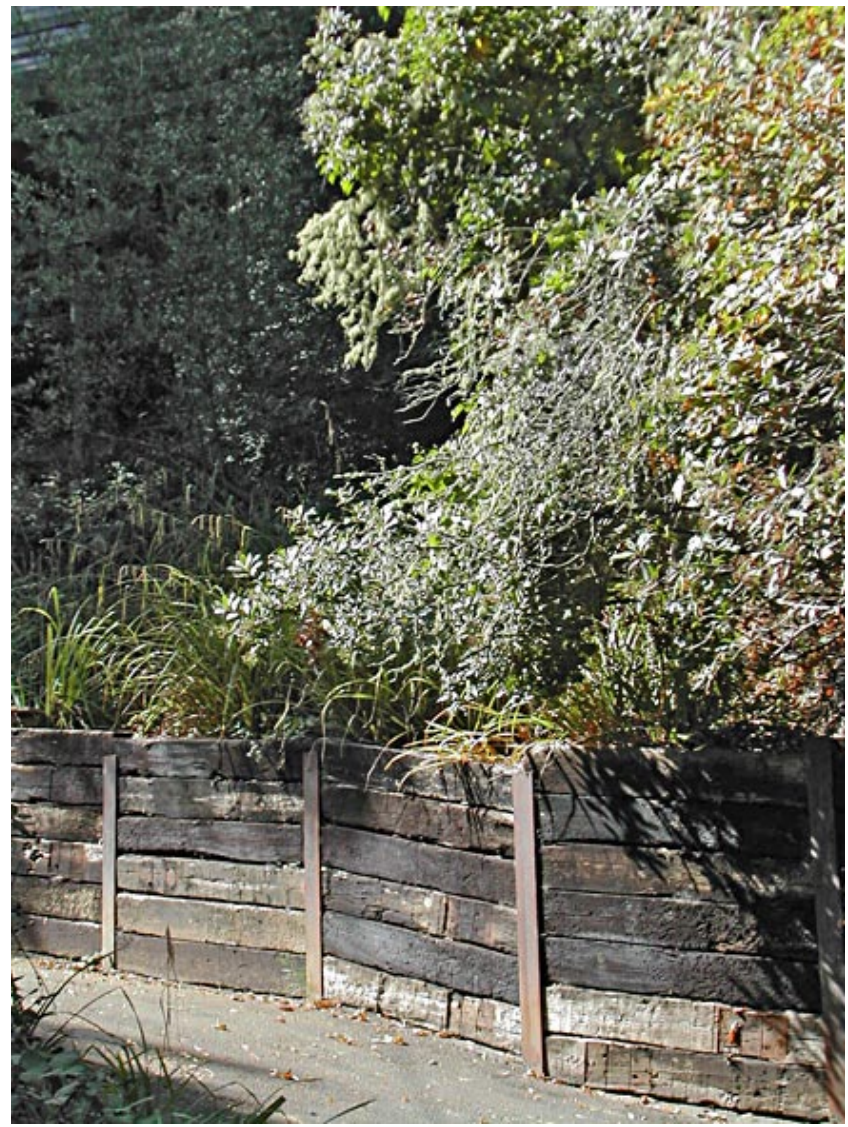

Figure 7. Salvaged creosote-treated railroad ties, now being used in a residential retaining wall.

\section{ACKNOWLEDGMENTS}

We gratefully acknowledge the help of William A. Dost and Kevin A. Flynn (wood performance consultants), Charles Jourdain (California Redwood Association), and John R. Shelly (UCCE Advisor) for participating in the survey that aided in preparation of the useful service life table (Table 3).

\section{REFERENCES}

Forest Products Laboratory. 1999. Wood handbook: Wood as an engineering material. Gen. Tech. Rep. FPL-GTR-113. Madison, WI: U.S. Department of Agriculture, Forest Service, Forest Products Safety Laboratory. 463 pp.

Laks, P. 1997. New wood preservatives on the horizon. Pages 15-20 in Second southeastern pole conference, T. L. Amburgey and H. M. Barnes, eds. Proceedings No. 7287. Madison, WI: Forest Products Society.

Mankowshi, M., and J. J. Morrell. 2000. Patterns of fungal attack in wood-plastic composites following exposure in a soil block test. Wood and Fiber Science 32(3):340-345.

Manning, M. J., and F. Ascherl. 2004. Borates as fungicides in wood-plastic composites. Pages 69-78 in Seventh International Conference on Woodfiber-Plastic Composites (and Other Natural Fibers), Proceedings No. 7242. Madison, WI: Forest Products Society.

Miller, D. J., and R. D. Graham. 1977. Service life of treated and untreated fence posts: 1976 progress report on the post farm. Research Paper 37. Corvallis: School of Forestry Forest Research Laboratory, Oregon State University, Corvallis.

Morrison, D. S. 2004. Pressure-treated wood: The next generation. Fine Homebuilding 160:82-85.

Pendleton, D. E., T. A. Hoffard, T. Adcock, B. Woodward, and M. P. Wolcott. 2002. Durability of an extruded HDPE/wood composite. Forest Products Journal 52(6):21-27.

Quarles, S. L., L. G. Cool, and F. C. Beall. 2004. Performance of deck board materials under simulated wildfire exposures. Pages 89-93 in Seventh International Conference on Woodfiber-Plastic Composites (and Other Natural Fibers), Proceedings No. 7242. Madison, WI: Forest Products Society.

Simpson Strong-Tie. 2004. Preservative-treated wood. Technical Bulletin T-PTWOOD04. Dublin, CA: Simpson Strong-Tie. http://www.strongtie.com/literature/tech-bulletins.html

US EPA. 2002. Manufacturers to use new wood preservatives, replacing most residential uses of CCA. Washington, DC: US Environmental Protection Agency. http://www.epa.gov/pesticides/factsheets/chemicals/cca_transition.htm 
Wilcox, W. W. 1984. The performance of Douglas-fir in normal residential service. University of California Forestry and Forest Products Note No. 53. Berkeley: California Agriculture Experiment Station.

\section{FOR MORE INFORMATION}

You'll find information on structural pest management in these titles and in other publications, slide sets, CD-ROMs, and videos from UC ANR:

Residential, Industrial, and Institutional Pest Control (Pesticide Application Compendium), Publication 3334

Wood Preservation (Pesticide Application Compendium), Publication 3335

Using CCA Preservative-Treated Lumber in Gardens and Landscaping, Publication 8128

To order these products, visit our online catalog at http://anrcatalog.ucdavis.edu. You can also place orders by mail, phone, or FAX, or request a printed catalog of publications, slide sets, CD-ROMs, and videos from

University of California

Agriculture and Natural Resources

Communication Services

6701 San Pablo Avenue, 2nd Floor

Oakland, California 94608-1239

Telephone: (800) 994-8849 or (510) 642-2431, FAX: (510) 643-5470

E-mail inquiries: danrcs@ucdavis.edu

An electronic version of this publication is available on the ANR Communication Services Web site at http://anrcatalog.ucdavis.edu.

\section{Publication 8144}

(C) 2004 by the Regents of the University of California, Division of Agriculture and Natural Resources. All rights reserved.

The University of California prohibits discrimination or harassment of any person on the basis of race, color, national origin, religion, sex, gender identity, pregnancy (including childbirth, and medical conditions related to pregnancy or childbirth), physical or mental disability, medical condition (cancer-related or genetic characteristics), ancestry, marital status, age, sexual orientation, citizenship, or status as a covered veteran (covered veterans are special disabled veterans, recently separated veterans, Vietnam era veterans, or any other veterans who served on active duty during a war or in a campaign or expedition for which a campaign badge has been authorized) in any of its programs or activities.

University policy is intended to be consistent with the provisions of applicable State and Federal laws.

Inquiries regarding the University's nondiscrimination policies may be directed to the Affirmative Action/Staff Personnel Services Director, University of California, Agriculture and Natural Resources, 300 Lakeside Drive, 6 ${ }^{\text {th }}$ Floor, Oakland, CA 94612-3550, (510) 987-0096. For information about obtaining this publication, call (800) 994-8849. For downloading information, call (530) 754-5112.

pr-12/04-WJC/CR

ISBN 978-1-60107-315-0

To simplify information, trade names of products have been used. No endorsement of named products is intended, nor is criticism implied of similar products that are not mentioned.

This publication has been anonymously peer reviewed for technical accuracy by University of California scientists and other qualified professionals. The review process was managed by the ANR Associate Editor for Pest Management. 